Midlands

Ashley Mobility, Hay Road, Hay Mills, Birmingham B25 8HY (021 7725364$)$

Derby Disabled Driving Centre, Kingsway Hospital, Kingsway, Derby DE3 3LZ (0332 371929)

Midland Cylinder Rebores Ltd, Torrington Avenue, Coventry, West Midlands CV4 9BL (0203 462424)

Ross Auto Engineering Ltd, 2/3 Westfield Road, Wallasey, Cheshire L44 7HX (051 653 6000)

North

Alfred Bekker, The Green, Langtoft, Near Driffield, North Humberside YO25 0TF (0377 87276)

Eurostag (Leeds) Ltd, Wellbridge Industrial Estate, Wellington Bridge, Leeds 12 (0532 444765)

Motor Services (Manchester) Ltd, Royal Works, Canal Side, Edge Lane, Stretford, Near Manchester M32 8HS (061 8656922$)$

SWS Motor Bodies, Unit 9, Hartford House, Newport Road, Weston Street, Bolton, Lancashire (0204 395660)

KC Mobility Services, Unit 4A, Victoria Mills, Bradford Road, Batley, West Yorkshire WF17 8LN (0924 442386)

\section{MOBILITY ALLOWANCE}

A non-taxable, non-contributory benefit paid monthly to severely disabled people aged over 5

To be eligible an applicant must: $(a)$ be unable to walk or virtually unable to walk; $(b)$ apply before 65 th birthday; and (c) be able to make use of the allowance (for example, not be in a coma)

It may be spent on any form of mobility assistance 16

It enables a person to hold a driving licence from the age of

It entitles a person to possess an orange badge for privileged parking

It gives exemption from vehicle excise licence duty (road $\operatorname{tax}$ )

It enables a person to use the motability scheme
MOTABILITY SCHEME

Motability is a voluntary organisation set up by government initiative to help disabled people use their mobility allowance in instalment payments to obtain a car or electric wheel chair. Hire purchase and hiring agreements are made with Motability Finance Ltd, a special company that negotiates favourable financial terms with motor manufacturers, banks, etc. When an agreement is entered into the entire mobility allowance must be paid over for the duration of the agreement (four and a half years for vehicle purchase, three years for vehicle hire). A list of cars available for purchase and hire and the cost is available from Motability. When a vehicle is hired the cost of servicing and repairs are included in the rental, but when a vehicle is being purchased the user must pay for the repairs and maintenance.

Further details are available from Motability, Gate House, West Gate, The High, Harlow, Essex CM20 1HR (0279 635666).

Further information and recommended reading

The ins and outs of car choice. London: Department of Transport and Institute of Consumer Ergonomics, 1985.

Cochrane GM, Wiltshire ER, eds. Outdoor transport. 6th ed. Oxford: Mary Marlborough Lodge, 1987. (Equipment for Disabled series.)

Roval Commission on Accident Prevention In: Raffle A, ed. Medical aspects of fitness to drive. London: HMSO, 1985.

Darnborough A, Kinrade D. Motoring and mobility for disabled people. 4 th ed. Darnborough A, Kinrade D. Motoring and mobility for disabled people.
London: Roval Association for Rehabilitation and Disability, 1988. London: Royal Association for Rehabilitation and Disability, 1988 .
Motability leaflet prepared by Motability, Gate House, West Gate, The High, Motability leaflet prepared by Motability, Gate House, West Gate, The High, Harlow, Essex CM20 1HR

Mobility Allowance. (Leaflet N1.211.) DSS Mobility Allowance Unit, Norcross, Blackpool FY5 3TA (0253 856123).

\section{Correction}

How district health authorities organise cervical screening An authors' error occurred in this paper by Dr Andrea Elkind and others (20 October, pp 915-8). In table III the number (percentage) of general practitioners usually to be informed of test results should read $173(98)$ and not $98(55)$ as published.

\title{
MATERIA NON MEDICA
}

\section{A burden laid down}

Pilgrimage - an old fashioned word not often used. My immediate image was of mediaeval Christians travelling to Rome or modern Muslims on the Haji to Mecca. Both encompass "a journey to a sacred place" and mine was no different from that. I have just had the privilege of providing medical cover for a Royal British Legion war graves pilgrimage to second world war graves in north Tunisia.

The background is interesting. Until the Falklands campaign in 1982 it was not the United Kingdom's practice to bring home the bodies of men and women who had died in conflicts overseas. After that conflict, however, the government funded a pilgrimage for relatives to visit graves in the Falklands. This factor, coupled with the discussions after the fortieth anniversary commemorations held in Bayeux, Normandy, in 1984 resulted in the announcement of the government grant in aid scheme, which in simple terms provides a war widow with seven eighths of the cost of visiting her late husband's grave overseas (provided she has not done so before at public expense). Since then some 2000 widows have used the scheme, and it is thought that there are up to 38000 who are still eligible to benefit.

The logistics of the pilgrimages are dealt with by the Royal British Legion (RBL) which acts as an agency for the government grant in aid scheme. It will organise pilgrimages to wherever there is a demand, and the scheme has visited cemeteries in the Far East and Africa as well as Europe.

Our pilgrimage consisted not only of war widows but also of siblings and children of those killed, together with veterans of the North Africa campaign. (Of course, only war widows are entitled to a subsidy.) We had a group of 48 with an administrative team of five, the RBL organiser, the RBL national executive committee representative (a retired lieutenant colonel who was a veteran of the campaign), the RBL standard bearer, a Queen Alexandra's Royal Army Nursing Corps sister, and myself.

And what of health? Before the pilgrimage the RBL arranged for general practitioners to complete health proformas. Of my pilgrims 21 claimed freedom from ailment, six had myocardial infarctions or angina, six were hypertensive, seven had joint pains, three were bronchitic, and eight had a variety of complaints. Fortunately, luck smiled on us and apart from the inevitable gastrointestinal upsets we had no major problems.
I should add that not all pilgrimages are free of injury and illness. The pilgrimage lasted a week, which meant that there was sufficient time to get to know the pilgrims and listen to their sometimes very sad tales - a splendid group of women they are. Now, a few weeks later, I am left with one overriding impression, which is the tremendous therapeutic value the pilgrimage had for all concerned. I give you three examples. The first was a widow whose husband was killed in 1943. She remarried, as did most of the widows, but her second husband was not happy with the idea of her visiting her first husband's grave-understandable, perhaps, but sad. Therefore she had to wait until widowed a second time before visiting her first husband's grave and achieving a "wish I have had for the past 47 years and never thought would come true." Similarly, there were children, now in their 50s, who cannot recall their father but wanted to visit his grave. Lastly, there was a quiet, shy lady. She had never remarried but had returned to her home city overseas and brought up her dead husband's children in difficult circumstances. Now they all have had the chance to complete their grieving.

After a rest day visits were organised to the eight Commonwealth War Graves Commission cemeteries in Tunisia. I accompanied the largest group to the main cemetery at Medjez-el-Bab. The sense of calm in the cemeteries is almost palpable, and the commission deserves praise for the beautiful gardens it tends so well. After this day many of the widows spoke not only of a fulfilment of a long held ambition but also of a sense of completeness as if a burden had been laid down.

Later in the week we had a service and wreath laying, which the British ambassador attended. That allowed the widows to place their personal grief in a more formal context, to the accompaniment of the RBL standard bearer and Tunisian army buglers.

"At the going down of the sun and in the morning/We will remember them." I trust so; certainly their widows do, and I hope you may be able to help those war widows who are your patients by putting them in touch with the pilgrimage department of the Royal British Legion. Then they too may be able to loose their burden of grief. - T P FINNEGAN, commanding officer, 4 Armoured Field Ambulance, RAMC 